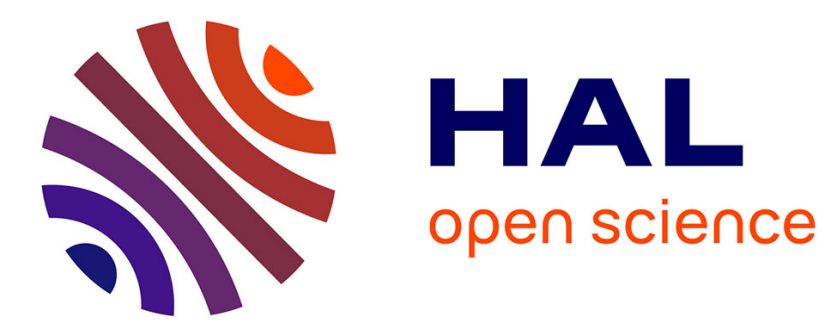

\title{
Competition policy in a concentrated and globalized retail industry
}

Stéphane Caprice, Vanessa von Schlippenbach

\section{To cite this version:}

Stéphane Caprice, Vanessa von Schlippenbach. Competition policy in a concentrated and globalized retail industry. Applied Economics Quarterly, 2008, 54 (3), pp.183-202. hal-02656654

\section{HAL Id: hal-02656654 \\ https://hal.inrae.fr/hal-02656654}

Submitted on 29 May 2020

HAL is a multi-disciplinary open access archive for the deposit and dissemination of scientific research documents, whether they are published or not. The documents may come from teaching and research institutions in France or abroad, or from public or private research centers.
L'archive ouverte pluridisciplinaire HAL, est destinée au dépôt et à la diffusion de documents scientifiques de niveau recherche, publiés ou non, émanant des établissements d'enseignement et de recherche français ou étrangers, des laboratoires publics ou privés. 


\title{
Competition Policy in a Concentrated and Globalized Retail Industry
}

\author{
Stéphane Caprice*, Vanessa von Schlippenbach** \\ Updated Version: September, 2008
}

\begin{abstract}
During the last decades the face of retailing has changed as a result of an ongoing concentration process and the emergence of increasingly large-scale retail outlets. Retailers constitute, therefore, "strategic gatekeepers" to final consumer markets providing them with buyer power vis-à-vis their suppliers. By preventing market entry, existing retail regulations have further strengthened the dominant position of retailers. In order to overcome the potential abuse of buyer power and thus to circumvent the induced inefficiencies, competition among retailers has to be encouraged. This gains in importance since the retail sector is also characterized by a strong internationalization process affecting both the worldwide spread of retail companies as well as their procurement strategies. In this regard, downstream competition is the only way to compensate the missing global legislation and jurisdiction.
\end{abstract}

Keywords: buyer power, retail regulation, globalization

JEL-Classification: K21, L 42

\section{Introduction}

The face of retailing has changed during the last few decades. Both the growing concentration among retailers as well as the ongoing consolidation process towards fewer but larger store outlets have significantly altered the vertical relations in the grocery channel. Since direct sales to final consumers have become less important, manufacturers have to pass the decision-making screen of a single dominant retailer in order to get their products sold in final consumer markets (FTC 2001). Access to retailer's shelf space is, therefore, essential to achieve final consumers which makes retailers "strategic gatekeepers" rather than competitive distributors of consumer products. This has improved retailers' bargaining position vis-à-vis suppliers. Correspondingly, retailers may force their suppliers to reduce the wholesale price below the level they would accept under more competitive circumstances and to extract other financial benefits from them. Retailers' buyer power has been strengthened further as both the high frequency of new product launches as well as the international procurement strategies by retailers intensify competition among suppliers for getting access to retail shelf space.

\footnotetext{
* Toulouse School of Economics (GREMAQ-INRA), Manufacture des Tabacs, Aile J.J. Laffont, 21 Allée de Brienne, F-31000 Toulouse, email: caprice@toulouse.inra.fr.

** Technische Universität Berlin and DIW Berlin, Mohrenstr. 58, D-10707 Berlin, e-mail: vschlippenbach@diw.de.
} 
The emergence of powerful retailers may create efficiencies. By negotiating better conditions in intermediate good markets, powerful retailers may counter selling power at the manufacturer level (Galbraith 1952). However, it is not clear whether retailers may pass the advantages to final consumers. Even the opposite can be true indicating that firms may increase consumer prices as a consequence of growing buyer power (Dobson and Waterson 1997, von Ungern-Sternberg 1996). Buyer power of large-scale retailers may also distort competition at both the retail as well as at the producer level to the consumer detriment. In particular, it is concerned that suppliers are increasingly squeezed by downstream retailers implying a reduced product variety in downstream markets. In turn, more standardized products will be distributed which are better adapted to the conventional needs of the mass. Referring to the classical hold-up (Williamson 1975), it is further complained that a powerful retail sector reduces suppliers' incentives to invest in higher product quality. All these concerns have been expressed in several formal investigations conducted by the EU (1999), the OECD (1998), and several national competition authorities in order to analyze mergers between retailers as well as particular procurement practices of retailers.

In this paper, we deal with some aspects of buyer power. For instance, we examine how retail regulation affect buyer power. In spite of liberalization efforts during the last decades, there is still a high level of regulation in the European retail sector. By preventing market entry, regulation at the retail level may strengthen the problem of buyer power by large-scale retailers. We also consider the implications of retailers' buyer power in an international perspective. The emergence of powerful retailers has often been viewed as an exclusive problem of industrialized countries. However, this is not the case anymore: Farmers and manufacturers in developing countries deliver their products either to domestic retailers which are often part of multinational retail firms or they sell their products to retailers in industrialized countries. Accordingly, they are confronted with an increasingly powerful retail sector. This raises the question how buyer power can be handled in an international perspective.

The remainder of the paper is organized as follows: In sections 2 and 3, we sketch the recent trends in retailing and retail regulations. Building on that, section 4 presents sources of buyer power referring to bargaining in intermediate good markets and consumers' shopping behavior. In section 5, we briefly summarize the consequences of buyer power. Section 6 provides an overview on the existing measures against buyer power. Finally, in section 7, we conclude.

\section{Trends in the Retail Industry}

Consumers and manufacturers mostly interact through intermediaries such as retailers. When the retail sector was highly fragmented and not very differentiated, the retail industry constituted a "transparent" window between suppliers and consumers. This perception has changed dramatically in the last couple of decades. Due to internal growth and mergers by leading retailers, the retail industry has become increasingly consolidated. Additionally, new store formats have emerged and more and more large retail chains have prevailed. As a consequence a limited number of large-scale retailers are prevalent and even dominant in their respective retail sectors. This pattern of development has been common all over Europe, even in developing countries the share of retail chains in total sales is growing. Among all areas of retailing, it is food retailing that has experienced the most profound changes (EU 1999, Dobson et al. 2001). 


\subsection{Retail Concentration}

Almost everywhere retailing is increasingly concentrated. The EU-15 has passed the most profound concentration process during the last few decades (see Table 1). The weighted average of the concentration ratio of the top-five retailers (CR 5) increased by more than 20 percentage points between 1993 and 2002 such that the CR 5 in most of the EU member states accounts for over 50\%. The only exception is Italy, where the top-five retailers accounted for not more than $37 \%$ of sales in grocery and daily goods retailing in 2002. This is due to the fact that in Italy even larger retailers constitute cooperatives which are at least locally embedded (Potz 2002). In Sweden, retail concentration is the highest in Europe with a CR 5 of 94.7\% in 2002. The strongest consolidation process between 1993 and 2002 was experienced by Greece, where the CR 5 increased from $10.9 \%$ to $52.7 \%$.

Table 1

Top-Five Concentration in Grocery and Daily Goods Retailing

\begin{tabular}{lccccc}
\hline Country & $\begin{array}{c}\mathbf{1 9 9 3}^{\mathbf{1}} \\
\mathbf{( \% )}\end{array}$ & $\begin{array}{c}\mathbf{1 9 9 6}^{\mathbf{1}} \\
\mathbf{( \% )}\end{array}$ & $\begin{array}{c}\mathbf{1 9 9 9}^{\mathbf{1}} \\
\mathbf{( \% )}\end{array}$ & $\begin{array}{c}\mathbf{2 0 0 2} \mathbf{2}^{\mathbf{2}} \\
\mathbf{( \% )}\end{array}$ & $\begin{array}{c}\text { 1993-2002 } \\
\text { percentage points }\end{array}$ \\
\hline Austria & 54.2 & 58.5 & 60.2 & 76.1 & +21.9 \\
Belgium + Luxemburg & 60.2 & 61.6 & 60.9 & 74.9 & +14.7 \\
Denmark & 54.2 & 59.5 & 56.4 & 77.8 & +23.6 \\
Finland & 93.5 & 89.1 & 68.4 & 73.3 & -20.2 \\
France & 47.5 & 50.6 & 56.3 & 77 & +26.5 \\
Germany & 45.1 & 45.4 & 44.1 & 67.9 & +22.8 \\
Greece & 10.9 & 11.8 & 17.6 & 52.7 & +41.8 \\
Ireland & 62.6 & 64.2 & 58.3 & 81.7 & +19.4 \\
Italy & 10.9 & 11.8 & 17.6 & 37 & +26.1 \\
Netherlands & 52.6 & 50.4 & 56.2 & 69.8 & +17.3 \\
Portugal & 36.5 & 55.7 & 63.2 & 67.4 & +30.9 \\
Spain & 21.6 & 32.1 & 40.3 & 60.4 & +38.8 \\
Sweden & 79.3 & 77.9 & 78.2 & 94.7 & +15.4 \\
United Kingdom & 50.2 & 56.2 & 63.0 & 57.9 & +7.7 \\
EU-15 weighted average & 40.7 & 43.7 & 48.0 & 69.2 & +21.7 \\
\hline
\end{tabular}

${ }^{1}$ European Retail Handbook in Dobson et al., 2003. ${ }^{2} \mathrm{M}+\mathrm{M}$ Planet Retail in: London Economics, 2004.

Although all European countries experienced similar patterns of consolidation, differences have occurred with respect to the emergence of retail formats. In particular, discount stores as well as hypermarket formats play an important role in food retailing, whereas the latter is characterized by a sales area of more than 1,500 $\mathrm{m}^{2}$. For example, Germany has seen the expansion of both format types. In 2005 the discounters increased their aggregate market share by 1.5 percentage points up to $24.5 \%$ 
and hypermarkets increased their market share by 0.5 percentage points. To the contrary, the market share of smaller retail formats with less than $800 \mathrm{~m}^{2}$ reduced by 2 percentage points. ${ }^{1}$

Compared to Europe, the concentration level of the retail industry in the U.S. is relatively low, though it is strongly increasing. While the 20 largest retailers account for $40.6 \%$ of total U.S. grocery sales in 1995, their market share increased to $61.6 \%$ in $2005 .{ }^{2}$ In developing countries, income growth and demographic factors like urbanization, working women etc. have indicated both a shift of consumption patterns towards higher value food products as well as an increasing importance of supermarkets in distributing food products. In Latin-America, supermarkets occupy meanwhile 50 to $60 \%$ of national food retail; in Southeast Asian supermarkets have a market share of roughly $33 \%$ and in East Asian countries of about 63\%. The highest growth rates of retail industries worldwide are observed in China; by 2003 it accounted for 30\% and is growing by 30 to $40 \%$ (Reardon et al. 2004). At present, supermarkets are just barely emerging in the poorest regions of the world like Bangladesh, Cambodia, and West-Africa (Reardon and Gulati 2003). Due to the increasing number of stores in particular regions, supermarket chains have replaced the per-store procurement system by a more centralized one. This is true for globally operating chains like Wal-Mart, Carrefour or Ahold but also for regional chains like China Resources Enterprises. Thus, with the emergence of supermarket chains in developing countries, suppliers face an increasingly consolidated retail industry they negotiate terms of delivery with. Of course, with the increasing dominance of retailers in developing countries, buyer power has become an issue.

\subsection{Internalization of Distribution and Procurement in the Retail Sector}

Beside consolidation the retail industry has undergone a strong internationalization process affecting both the spread of retail companies worldwide as well as their procurement strategies. The largest retail companies have expanded their activities to various countries. An increasing share of their sales, therefore, takes place in foreign countries (see Table 2). One notable exception is Wal-Mart that dominates the global grocery sector, although it is mainly active in the U.S.

The incentives of retail chains to invest in foreign countries, in particular in developing countries, result from softer regulatory frameworks and weaker competition in these markets. Thus, market entry in developing markets enables retail companies to extract higher profit margins (Reardon et al. 2004). ${ }^{3}$

\footnotetext{
${ }^{1}$ Bundesverband des deutschen Lebensmitteleinzelhandels (2005), pp. 17-21.

${ }^{2}$ USDA, ERS, Amber Waves, 02/2007.

${ }^{3}$ Carrefour, for example, got three times higher margins in Argentina then in France (Gutman 2002).
} 
Table 2

Top 10 Grocery Retailers Worldwide

\begin{tabular}{llrrrrrrrr}
\hline & & $\begin{array}{c}\text { Retail Banner } \\
\text { Sales (USD bn) }\end{array}$ & \multicolumn{2}{c}{$\begin{array}{c}\text { Grocery Sales } \\
\text { (\%) }\end{array}$} & \multicolumn{2}{c}{$\begin{array}{c}\text { Domestic Sales } \\
\text { (\%) }\end{array}$} & \multicolumn{2}{c}{$\begin{array}{c}\text { Foreign Sales } \\
\text { (\%) }\end{array}$} \\
& & \multicolumn{1}{c}{2004} & $2009^{*}$ & 2004 & $2009^{*}$ & 2004 & $2009^{*}$ & 2004 & $2009^{*}$ \\
\hline Wal-Mart & USA & 309.4 & 426.1 & 45 & 46 & 77.8 & 77.5 & 22.2 & 22.5 \\
Carrefour & France & 113.0 & 164.7 & 75 & 74.3 & 49.1 & 74.3 & 50.9 & \\
Ahold & Netherlands & 89.4 & 99.5 & 84 & 84.4 & 16.6 & 17.6 & 83.4 & 82.4 \\
Metro Group & Germany & 77.8 & 109.5 & 49 & 48.9 & 52.3 & 45.9 & 47.7 & 54.1 \\
Tesco & UK & 68.2 & 102.3 & 74 & 73.4 & 79.3 & 70.8 & 20.7 & 29.2 \\
Kroger & USA & 58.6 & - & 70 & - & 100 & - & 0 & - \\
Ito-Yokado 1 & Japan & 63.2 & 87.3 & 66 & 64.6 & 67.9 & 67.8 & 32.1 & 32.2 \\
Rewe & Germany & 54.8 & - & 76 & - & 71.6 & - & 28.4 & - \\
Target & USA & 53.9 & - & 32 & - & 100 & - & 0 & - \\
Costco & USA & 51.2 & - & 60 & - & 80.3 & - & 19.7 & - \\
\hline
\end{tabular}

Source: Planet Retail Ltd. *Forecast by Planet Retail Ltd.

However, the internalization of retailing does not only trace back to foreign investment in retail outlets. Trade liberalization and innovations in transport systems made the procurement systems more international. Interestingly, intermediate goods and thus inputs are more often traded than final consumer products. This comes along with a high level of international disintegration of multistage production. About half of the total imports in developed countries are imported inputs. Due to the stronger growth of trade relative to production, the share of imported inputs in total inputs increased strikingly (Kleinert 2003). The share of imported inputs relative to total inputs increased from 5.3\% to 11.6 \% between 1972 and 1990 in the U.S (Feenstra and Hanson 1996). Campa and Goldberg (1997) find similar results for Canada and the UK. Since the 1980s, the exports from developing countries become increasingly important. Over this period, the U.S. imports from China have increased by 30 times, whereas Wal-Mart accounts today for 15\% of total US-imports from China (Basker and Van 2005). And the value of exports of fresh vegetables from sub-Saharan Africa to the European Union increased by 150\% (Dolan and Humphrey 2001). This development is especially true for the growing retail industry. Retailers are establishing strong ties with global suppliers, in particular with suppliers from low cost countries (Gereffi 2001). Dolan and Humphrey (2001) highlight the decisive role British retailers play in organizing the production and processing of vegetables mainly imported from Africa. Due to their essential gatekeeper position in vertical chains, retailers may decide on the inclusion or exclusion of producers inducing vertical dependencies as well as a shift of bargaining power to retailers. 


\section{Retail Regulations}

Beside structural changes the retail industry is also characterized by a strong regulatory framework. ${ }^{4}$ The basic intention of retail regulations is to protect small retailers against large retailers. However, such rules have created and strengthened barriers to entry in retail markets. By preventing market entry and thus enhancing retailers' gatekeeper control to final consumer markets, retail regulations may improve buyer power in the retail sector as they reduce selling alternatives of manufacturers. In the following we focus on the structural effects of planning restrictions and regulations of shopping hours.

\subsection{Planning Restrictions}

According to the OECD, France is the country with the highest regulation inducing barriers to entry in the distribution sector. All retail outlets with more than $300 \mathrm{~m}^{2}$ required public permission. ${ }^{5}$ This regulation in retail distribution encouraged buyer mergers and contributed to strengthen the retailers' position vis-à-vis their suppliers. In France, the major four distribution groups totalize $66 \%$ of market shares. Moreover, and maybe more importantly, more than $85 \%$ of small outlets between 200 and $1200 \mathrm{~m}^{2}$ belong to large distribution groups.

Previously, In Italy, market entry of retailers was restricted by a public license system enacted in 1926 and a town-planning act from 1942 in order to secure the fragmented retail structure. This system was amended in 1971 in order to facilitate the market entry of larger retail outlets. Hence, since 1971, retailers with sales areas over $1,500 \mathrm{~m}^{2}$ required Regional Authority permission, while retailers over $400 \mathrm{~m}^{2}$ only required local municipality permission. Even if the license and permission system has been abolished by the Bersani-Amendment in 1998, there are still planning restrictions. It is the same in Germany where there is no tendency to liberalize existing planning restrictions. That is, retailers with sales areas over $800 \mathrm{~m}^{2}$ are limited in their choice of location; they are only allowed to settle down in particular areas called "Kern- und Sondergebiete" in order to reduce their negative impact on town planning and traffic in residential areas. These severe restrictions could be the reason for the extreme expansion of discount stores in Germany as they typically cover about $400 \mathrm{~m}^{2}$.

Although retailing in the UK is less restricted than in most other European countries, planning rules were sharpened in the 1990s. In 1993, the government issued a revised Planning Policy Guidance, which strongly favoured sites in town centers. Given the lack of large sites available in town centers, this severely limited the number of large stores that were built. However this regulation did not lead to a reduction in the number of new store openings, but did affect the size and location of new stores. Less restrictive planning rules apply in the U.S.

Even though there is no academic work it is conventional wisdom that both retail mergers and the emergence of larger-scale retail outlets on the outskirts of towns were driven by planning rules in retail distribution. Thus, regulations concerning commercial zoning are among the greatest entry barriers to retail markets. The cost advantages and the incumbent advantages that large grocery retailers have over grocery retailers and new entrants are other factors that may prevent entry or expansion in grocery retailing.

\footnotetext{
${ }^{4}$ For a detailed analysis of regulation practices in retailing see Faini et al. (2006).

${ }^{5}$ Recently, planning restrictions have been relaxed such that only the establishment of retail outlets with sales areas with more than $800 \mathrm{~m}^{2}$ require permission.
} 


\subsection{Shopping Hours}

While the effort to liberalize planning restrictions is relatively low in most European countries, a great deal of effort has been undertaken in order to soften other fields of regulation. That is, regulation particularly restricting retailers' shopping hours has been relaxed in most European countries. For example, since 1998 Italian retailers have been allowed to keep their stores open until 10 p.m. on week days. Similarly, in Germany for a long time shops were obliged to close at 6.30 p.m. on weekdays and at 2 p.m. on Saturdays. The regulatory framework with respect to shopping hours was softened when the Länder obtained the responsibility of shopping hours in the course of the "Federalism Reform" in 2006. Since then shops are allowed to stay open on weekdays until 8 p.m. and on Saturdays until 4 p.m. The UK was already starting to deregulate the retail industry in the 1980s. The "Sunday Trading Act" enacted in 1994 prohibits retail outlets covering more than 280 square meters to open more than six hours on Sundays.

The literature shows that the effects of deregulated shopping hours are ambiguous. For example, Inderst and Irmen (2005) show that retailers regard the choice of opening hours as a measure to increase the degree of perceived product differentiation thus relaxing price competition. Hence if the consumers' preference for time is sufficiently high retailers differentiate in opening hours, charging higher prices and being both strictly better off than under regulation. Correspondingly, the increase in retail profits can enhance market entry. In turn, Morrison and Newman (1983) and Tanguay et al. (1995) show that prices increase at large stores, while they decrease at small stores. Nevertheless the demand shifts to large stores enhancing the consolidation process in the retail industry.

\section{Some Determinants of Buyer Power}

This section presents different sources of buyer power in the retail industry. Firstly, we analyze how buyer power emerges in bilateral negotiations over supply contracts. We then examine the ambiguous implications of one-stop shopping behavior for the retailer's bargaining position.

\subsection{Bargaining and Buyer Power}

Formal analysis has often neglected the strategic role retailers have obtained in value chains. Despite the increasing importance of retailers, the retail industry has been seen as a "transparent window" to final consumer markets. This approach neglects imperfect competition on both sides and thus the problem of bilateral bargaining power. The recent literature on retailers' buyer power in vertically related markets builds on the tools of modern bargaining theory such as non-cooperative multilateral bargaining. Some papers model negotiations as simultaneous and separate (see for example Hart and Tirole 1990, McAfee and Schwartz 1994). In that case, the bargaining outcome is assumed not to be contingent on whether or not negotiations of rival pairs are successful (Rey and Vergé 2004). In contrast, Inderst and Wey (2003) or de Fontenay and Gans (2005) postulate that the contract terms of a bargaining pair are contingent on a rival pair's disagreement. The assumption captures the idea that a negotiation breakdown is permanent and irrevocable, and therefore common knowledge. 
The recent literature on buyer power advances some interesting explanations as to why larger retailers may get better terms of trade in intermediate good markets. Size may increase the retailer's buyer power by raising the value of her own outside option. If a buyer is large enough, she can credibly threaten to integrate backwards, thereby rendering the supplier redundant (Katz 1987, Sheffman and Spiller 1992). Similarly, large buyers are able to introduce competition in upstream markets by establishing a private label. ${ }^{6}$ Stronger buyer power also emerges as a consequence of reducing the supplier's outside option. In the case of negotiation break-down, Inderst and Wey (2007a) claim that suppliers find it difficult to unload the cancelled demand onto the remaining buyers as this involves "marching down" the declining marginal surplus functions. Chipty and Snyder (1999) and Raskovich (2003) assume that buyers negotiate with a monopoly supplier. If the aggregate surplus function across all negotiations is concave in quantity, the incremental surplus increases more than proportionally in buyer size, which explains why large buyers pay a lower price per unit. Considering competing suppliers instead, Snyder $(1996,1998)$ shows that collusion of suppliers is difficult to sustain in the presence of large buyers, because such buyers are more likely to tempt an individual supplier to deviate from the collusive strategy. To understand this effect, note that the larger the buyer, the more a supplier can win if she deviates. To prevent undercutting in equilibrium, suppliers have to collude on lower prices for large buyers. A further key determinant of buyer power is the number of goods that an outlet stocks. After a merger or the formation of a buyers' alliance the new entity may announce that she will no longer stock the goods of all previous suppliers which increases the intensity of upstream competition (Dana 2006, Inderst and Shaffer 2007). Baake and von Schlippenbach (2008) show that retailers improve their bargaining position in intermediate good markets by using upfront payments and reducing the number of products they sell to final consumers.

\subsection{One-Stop Shopping: An Additional Driver of Buyer Power}

The development towards powerful retailers has been favored by consumers' preference for onestop shopping. Due to the increase in both the requirements in professional life and the estimation of spare-time activities, time has become more and more scarce. Growing opportunity costs of time favor the economization on shopping time (Carlson and Giesieke 1983), followed by an increasing tendency towards one-stop shopping in consumers' behavior. That is, consumers prefer to bundle their purchases (Dellaert et al. 1998) in order to reduce their shopping costs instead of wasting their time by shopping at different stores. By bundling their demand for goods from different categories and by reducing their shopping trips to a main-trip which they then complete with smaller top-up trips in a particular period of time, consumers realize economies of scope and economies of scale. According to a survey by the UK Competition Commission (2000), about 70\% of consumers evince one-stop shopping behavior in spending about $80 \%$ of their weekly expenditures on fast-moving consumer goods on a weekly main trip. Smith (2007) empirically investigates consumer shopping behavior and supermarket choice pointing out the coexistence of "one-stop" or "two-stop" shopping behaviour. Although the goods included in consumers' shopping basket may be substitutes, complements or independent goods from a consumption point of view, it is conventional wisdom that goods become complementary if they are bundled by consumers making competition among retailers fiercer (Beggs 1994). ${ }^{7}$

With respect to the relation between suppliers and retailers, consumers' preference for one-stop shopping raises the suspicion that the bargaining position of popular brand manufacturers may be

\footnotetext{
${ }^{6}$ Bergès-Sennou et al. (2004) provide a survey on the economic literature of private labels.

${ }^{7}$ Seminal references in economics are Stahl (1987), Bliss (1988) and Lal and Matutes (1989).
} 
improved, while producers of bulk goods may lose. This is due to the fact that consumers preferring one particular brand do not enter a store that does not offer their favourite brand. Thus, the retailer loses the demand for the whole shopping basket of the consumer when she does not offer the consumer's favourite brand. Obviously, this improves the bargaining position of the brand manufacturer. However, one-stop shoppers tend to substitute such goods for which they only have weak preferences instead of changing the store in order to get their favourite product. Correspondingly, the retailer can credibly threat to delist these products which in turn improves her bargaining position.

\section{Welfare Effects of Buyer Power}

Building on the different sources of buyer power, we turn to its potential consequences. Though buyer power enables the retailer to negotiate better terms of trade in intermediate good markets, it is not clear whether the individually negotiated discounts are passed through to final consumers. We further examine how retailers' buyer power may affect suppliers' incentives to innovate and invest.

\subsection{Advantages of Buyer Power? Pass Through?}

One potential advantage of buyer power is that lower purchasing costs resulting from the exercise of buying power can lead to lower prices for consumers. However, as stated by the European Commission Guidelines: "the primary concerns in the context of buying power are that lower prices may not be passed on to customers further downstream and that it may cause cost increases for the purchasers' competitors on the selling markets because either suppliers will try to recover prices reductions for one group of customers by increasing prices for other customers or competitors have less access to efficient suppliers." ${ }^{8}$ Buyer mergers are not always pro-competitive. Dobson and Waterson (1997) consider the effects of increased retail concentration on consumer prices and welfare within a market setting where imperfectly competitive retailers negotiate intermediate prices with a monopoly supplier. Only when retailer services are regarded as very close substitutes, final prices fall as a consequence of a reduction in the number of retailers. ${ }^{9}$ Moreover, as added by the European Commission, if a powerful retailer obtains a discount that is, at least partially, passed through to final consumers by lower retail prices, less powerful retailers prices may increase. Known as a waterbed-effect, the mechanism is the following: significant buyer power by one group of buyers may lead to cost increases for its competitors because suppliers will try to recover price reductions for one group of buyers by increasing prices for other buyers, which are passed through by higher retail prices. Recent economic research has provided some theoretical foundations for a possible waterbed-effect. If the rise of a powerful buyer deteriorates smaller and less powerful buyers' bargaining position, their current suppliers may be able to raise prices. In the face of more competitive pricing by a powerful buyer, smaller and less powerful buyers may have weaker competitive position and smaller volume

\footnotetext{
${ }^{8}$ Guidelines in the applicability of Article 81 of the EC Treaty to horizontal cooperation agreements (2001/C3/02), paragraph 126.

${ }^{9}$ See also von Ungern-Sternberg (1996).
} 
which make them less attractive for suppliers. This, for example, might make it less credible and profitable for them to switch suppliers, deteriorating their outside option. ${ }^{10}$

However, as shown by Chen (2003), the opposite argument may be provided. If a supplier decides on her list prices for small buyers strategically, she may find it profitable to reduce list prices in order to increase its negotiation power vis-a-vis a more powerful buyer. ${ }^{11}$ One key aspect of this model is the sequence of contract negotiations with different retailers. It appears reasonable indeed to assume that suppliers are able to commit to contracts with smaller and less powerful buyers, the same cannot be said about contracts with a more powerful buyer. Its countervailing power should enable it to enforce renegotiations if it does not like the original contract terms. Formally, negotiations are made sequentially and the supplier sets prices to small buyers in order to undermine the outside option of the more powerful buyer.

In theory, price differentials leading to a waterbed-effect and to increased average prices for consumers might arise under some circumstances. However, data for the UK market which is the most complete investigation of the supply of the groceries supports the view that if any waterbed effect exists, it probably only affects prices in a marginal way. ${ }^{12}$ The general idea to keep in mind is probably the following: If buyers have too much power on the selling markets, the cost savings are probably not passed on to consumers.

\subsection{Buyer Power and Upstream Investments}

Turning to the relation between buyer power and the suppliers' incentives to innovate, it is often suggested that suppliers respond to the exercise of buyer power "by under-investing in innovation and production" (FTC 2001, p. 57). If it were possible for suppliers and buyers to contract on innovations and production, investment maximize the joint profits from their transactions. However, investment is not contractible and suppliers may have inadequate incentives to undertake the required investment. More powerful buyers can extract larger fractions of all future profits and incentives to invest are undermined. ${ }^{13}$

Inderst and Wey (2007b) qualify this view and show that buyer power tends to increase suppliers' incentives at the margin. If a buyer controls a large share of the market it may be particularly important for the supplier to innovate as this will make it easier to sell through various alternative channels. Furthermore, by innovating, a supplier can take advantage of a strategic bargaining effect: innovation increases the loss that the supplier is able to inflict on a retailer by supplying only its rivals. This reduces the outside option of a retailer allowing the supplier to extract more bargaining surplus through fixed fees. ${ }^{14}$

The presence of large buyers may also help to overcome buyers' coordination failures which might prevent entry in an industry with an incumbent firm and a more efficient potential entrant (Fumagalli

\footnotetext{
${ }^{10}$ See Majumdar (2006) and Inderst and Valetti (2007) for formal argument and Dobson and Inderst (2007) for a more general policy discussion of the waterbed-effect, notably in the long run.

${ }^{11}$ See Caprice (2006) and Inderst and Wey (2007b) where such a strategy to undermine the value of buyers' outside options is also considered.

12 “The supply of groceries in the UK market investigation”, Competition Commission, 30 April 2008.

${ }^{13}$ See for example Chen (2004) who applies this to analyze the effects of countervailing power on product diversity and Battigalli et al. (2007) who study this in a context of investment in quality improvements.

${ }^{14}$ See also Faulí-Oller et al. (2007) who show that downstream mergers increase the incentives of an upstream firm to invest in cost-reducing R\&D.
} 
and Motta 2008). Fewer and larger buyers reduce co-ordination problems making exclusion less likely. Nevertheless, importantly, at the same time, for any given number of buyers, exclusion is less likely the more fiercely buyers compete in the downstream market. The presence of fewer and larger buyers is pro-competitive but downstream competition should be effective to promote upstream entry or upstream innovation as previously.

\section{Buyer Power and Competition Policy}

As illustrated above, the trends in retail distribution have raised concerns about retailers that abuse their dominance vis-à-vis manufacturers. ${ }^{15}$ Although it is argued that buyer power can be socially beneficial by countering the market power of manufacturers and thus leading to lower prices in final consumer markets, there is a growing concern that retailers' buyer power may negatively affect suppliers in both a static and dynamic perspective. Accordingly, questions of how buyer power should be treated in antitrust policy have gained prominence. This refers mainly to mergers and vertical restraints. Nevertheless the European Commission have remained largely impassive with respect to the observed increases in buyer concentration in Europe, particularly in the retail sector. Though there exist antitrust laws and competition policies towards mergers and vertical restraints, they primarily apply to the treatment of supplier power while buyer power was long time neglected. However, the subject of buyer power was raised in both the European Commission's Green Paper on Vertical Relations introducing new block exemptions and policy guidelines as well as in the Commission's investigations of merger proposals (Dobson et al. 2001).

The assessment of horizontal mergers in European competition law traces back to the Merger Regulation 4064/89 and successive modifications indicating that mergers which create or reinforce a dominant position are prohibited. This refers to mergers that allow for raising prices or facilitate collusion. However, in the assessment of several merger proposals, in particular in the heavily concentrated retail industry, the issue of growing buyer power as a result of a merger gained in importance. ${ }^{16}$ This is also true for the establishment of buying groups. For instance, the German Competition Authority (Bundeskartellamt) recently rejected the procurement cooperation of EDEKA and Kaiser`s Tengelmann anticipating the growth of dominance in intermediate good markets. ${ }^{17}$ However, with respect to the globalized retail industry, merger control fails to prevent buyer power as it is not internationally applicable. This, in turn, makes measures against the abuse of buyer power increasingly important as they protect small suppliers facing a globalized retail industry against the exploitation and other negative implications of retailers' buyer power.

In the following subsections we review briefly the attitude of competition policy towards buyer power focussing on measures against the abuse of a dominant position in vertical relations such as vertical dependency, price discrimination as well as resale price maintenance.

\footnotetext{
${ }^{15}$ European Commission's Green Paper on Vertical Restraints, released in January 1997

${ }^{16}$ Compare Rewe/Meinl (Case no IV/M.1221), Kesko/Tuko (Case no. IV/M. 784), and Carrefour/Promodes (Case no IV/M. 1684).

${ }^{17}$ Press Release of the German Federal Competition Authority, 01/07/2008.
} 


\subsection{Prohibitions of Abuse of Economic Dependency}

One of the main concerns with respect to buyer power of large retailers refers to potential inefficiencies such as quality reductions and reduced innovation efforts at the supplier side. As a consequence, prohibitions against the abuse of economic dependency have been implemented. Arising first in Germany (1973), such prohibitions then spread to France (1986) and later to Portugal (1993). Their basic intention was to extend the application of abuse of dominance laws to buyers, which are not dominant in their selling markets but anyway in a powerful position vis-à-vis their suppliers. In some European countries, prohibitions against the abuse of economic dependency have been established.

In Germany, abuse of buyer power includes all practices which may either limit real and potential trading partners in their freedom to act or harm horizontal competition. The abuse of buyer power is prohibited for all firms which are either dominant or which small and medium sized sellers depend on. This is the case when a seller has no possibility to switch to another buyer. Thus, the abusive exploitation is forbidden when either the customer or the supplier has no equivalent alternative. This may refer to a refusal to supply, tied sales, price discrimination in intermediate good markets, and other vertical practices like entry or listing fees in particular at retail stores (EU 1999). Similar legislations exist in France. Referring mainly to horizontal competition, it is intended to prevent small and medium-sized firms from their powerful competitors and their ability to negotiate better terms of trade in intermediate good markets.

Such prohibitions do not appear to be very successful in controlling abuse of market power. This is due to the fact that economic dependency laws rely on the need to prove (i) the status of dependency, (ii) its abuse, and (iii) the effect on the market. Furthermore, affected firms avoid to make complaints for fear of losing their buyers and thus business. However, these laws may be best suited to prevent post-contractual opportunism indicated by delaying payments to suppliers or the demand for additional payments like so-called “wedding gifts” when retailers merge (Dobson 2002).

\subsection{Forbidding Price Discrimination in Intermediate Good Markets}

U.S. competition authorities' recognition of the importance of powerful buyers long precedes European concerns in recent years. The rise of mass retailers in the 1930s like A\&P, Sears, and Roebuck \& Co. led their smaller competitors and their suppliers to pressure legislators to prohibit preferential pricing for selected buyers. These lobbying efforts produced the Robinson-Patman Act in 1936, an amendment to Section 2 of the Clayton Act, forbidding price discrimination in input markets. Thanks to this legislation, the Federal Trade Commission succeeded in prosecuting and obtaining cease-and-desist orders in more than one thousand cases of third-degree price discrimination from 1936 to 1972. Price discrimination in input markets is also forbidden in some European countries such as in France and Germany.

There has been considerable back and forth in the academic literature on price discrimination in intermediate good markets. The recent theoretical literature identified several welfare gains from forbidding price discrimination in intermediate-good markets (Katz 1987, DeGraba 1990, Yoshida 2000). While these results rely on linear prices, Rey and Tirole (2007) analyze nonlinear prices and show that banning price discrimination can actually reduce social welfare. Uniform pricing relaxes the commitment problem emphasized by Hart and Tirole (1990) and McAfee and 
Schwartz (1994) and thus restores the supplier's ability to leverage his monopoly power. Caprice (2006) qualifies some of these conclusions by allowing for fringe competition of less efficient suppliers. Upstream competition leads to a new bargaining effect in addition to the commitment effect in Rey and Tirole (2007). The bargaining effect relies on the outside options of retailers. Banning price discrimination may cause per-unit prices to fall and welfare to increase since reducing the per-unit price makes the outside option of buying from the fringe less profitable. Decreasing per-unit prices allows the supplier to extract more bargaining surplus through fixed fees. However, assuming that breakdowns in negotiations over wholesale contracts are verifiable as well as observable and therefore contractible (as do, for example, Inderst and Wey (2003), or de Fontenay and Gans 2005) leads to the result of Rey and Tirole (2007) according to which banning price discrimination reduces social welfare.

\subsection{RPM: An increasing Concern of Competition Authorities?}

Although the attitude of competition authorities towards non price vertical restraints has changed over the years, price restraints like RPM (Resale Price Maintenance) are banned per se both in the European Union and the United States. For instance the Commission's view can be illustrated with the Pronuptia decision in which the Commission found that RPM was restricting intraband competition ${ }^{18}$ : "certain provisions restrict competition between the members of the network. That is true of provisions ... which prevent franchisees from engaging in price competition with each other.” RPM is thus illegal per se. With the emergence of powerful buyers, RPM practices changed. For example in 2005, the French competition authority (The Conseil de la Concurrence) imposed penalties on BVHE (Buena Vista Home entertainment), the exclusive supplier of Disney in France and three downstream firms, Casino, Carrefour and SDO (Selection Disc Organization, a wholesaler) for engaging in a price fixing agreement on the retail price. ${ }^{19}$ This was complemented by collecting, sharing and monitoring information between the firms in order to consolidate the system. More recently, in 2007, five toy manufacturers and three retailers have been condemned by the Conseil de la Concurrence for agreeing to fix resale prices. Since retailers concerned actively participated in these practices ${ }^{20}$, total fines amount to 30 million Euros for retailers and 7 million Euros for suppliers.

Recent results in the literature provide clear arguments supporting a per se ban of RPM. Rey and Vergé (2004), Dobson and Waterson (2007) or Allain and Chambolle (2007) have shown that RPM or a price-floor-restraint could suppress competition among producers as well as among retailers. The role of buyer power in mitigating or enhancing the scope for collusion among upstream suppliers has been analyzed too. In a first stream, retailers' buyer power is traditionally considered as a limiting factor for upstream collusion by competition authorities. However, recent cases such as the last decision of the Conseil de la Concurrence in 2007 suggest that the scope of RPM practices has increased and that the coexistence of seller and buyer power may play a crucial role.

\footnotetext{
${ }^{18}$ See official Journal of the European Communities 13, 15 January 1987.

${ }^{19}$ See Decision $n^{\circ} 05-\mathrm{D}-70$ of $19^{\text {th }}$ December 2005.

20 "This was notably the case of Carrefour, which set up a promotional campaign called 'Carrefour reimburses the difference times 10' for several successive years, thus encouraging consumers to monitoring prices on its behalf. Using information obtained when reimbursing consumers, Carrefour systematically asked the relevant suppliers to 'solve the problem' caused by the lower prices offered by its competitors." See Decision 07-D-50 of 20 December 2007.
} 


\section{Conclusion}

During the last decades the retail industry has become increasingly consolidated. This process was accompanied by the emergence of new store formats and large retail chains. This has improved retailers' bargaining position vis-à-vis suppliers. Furthermore, we identified consumers' one-stop shopping as well as existing retail regulations like planning restrictions and regulated shopping hours as additional drivers of retailers' buyer power. Retail regulations enhance retailers' gatekeeper control to final consumer markets by preventing market entry of potential competitors. At the same time, trade liberalization and innovations in transport systems induced the internationalization of retailing. Since manufacturers deliver their products either to domestic retailers which are often part of multinational firms or sell them to industrialized countries, buyer power of a consolidated retail industry has become an international issue.

Though buyer power may create efficiencies by negotiating better terms of trade with upstream suppliers, it may also distort competition at both the upstream and the downstream level. Due to the internationalization of retailing, it is, however, not clear whether antitrust measures such as merger control that aim at preventing the further increase in retailers' buyer power may be appropriate to tackle buyer power in an international perspective. This is due to the fact that there exists no international competition law forbidding mergers between dominant retailers in different countries such that the emergence of powerful global retail chains cannot be avoided. That is, there is no legal framework that can be applied. And of course it would be difficult to implement one.

In order to circumvent inefficiencies induced by powerful global retailers, retail competition has to be enhanced at a national level or at a local level. By reducing barriers to entry into retail activities, buyer power of large retailers can be reduced as manufacturers obtain an alternative to deliver their products. This has to come along with the strengthening of measures against the abuse of buyer power. In this way, UK Competition Commission propose local competition test for every new outlet to favour entry of new competitors in retail industry.

\section{References:}

Allain, M.L / C. Chambolle (2007): "Anticompetitive Effects of Resale-Below-Cost Laws," CREST Working Paper No. 2007-29.

Baake, P. / von Schlippenbach, V. (2008): "Upfront Payments and Listing Decisions,“ DIW Discussion Paper.

Basker, E. / Van, P.H. (2005): "Putting a Smiley on the Dragon: Wal-Mart as Catalyst to US-China Trade,” University of Missouri, mimeo.

Battigalli, P. / Fumagalli, C. / Polo, M. (2007): "Buyer Power and Quality Improvement,” Research in Economics 61, 45-61.

Beggs, A.W. (1994): “Mergers and Malls,” Journal of Industrial Economics 42, 419-428.

Bergès-Sennou, F. / Bontems, P. / Réquillart, V. (2004): "Economics of Private Labels: A Survey of Literature," Journal of Agricultural \& Food Industrial Organization, 2, 1037-1037. 
Bliss, C. (1988): “A Theory of Retail Pricing,” Journal of Industrial Economics 36, 375-391.

Bundesverband des deutschen Lebensmitteleinzelhandels (2005): "Branchenreport”.

Campa, J.M. / Goldberg, L.S. (1997): "The Evolving External Orientation of Manufacturing: A Profile of Four Countries,” Economic Policy Review 3(2).

Caprice, S. (2006): "Multilateral Vertical Contracting with an Alternative Supply: The Welfare Effects of a Ban on Price Discrimination,” Review of Industrial Organization 28, 63-80.

Carlson, J.A. / Gieske, R.J. (1983): "Price Search in a Product Market,” Journal of Consumer Research 9, 357-365.

Chen, Z. (2004): “Countervailing Power and Product Diversity,” mimeo.

Chen, Z. (2003): "Dominant Retailers and the Countervailing Power Hypothesis,” RAND Journal of Economics 34, 612-625.

Chipty, T. / Snyder, C.M. (1999): "The Role of Firm Size in Bilateral Bargaining: A Study of the Cable Television Industry,” Review of Economics and Statistics 81, 326-340.

Dana, J. (2006): “Buyer Groups as Strategic Commitments,” Northwestern University Working Paper.

de Fontenay, C.C. / Gans, J.S. (2005): "Vertical Integration in the Presence of Upstream Competition,” RAND Journal of Economics 36, 544-572.

DeGraba, P. (1990): "Input Market Price Discrimination and the Choice of Technology," American Economic Review 80, 1246-1253.

Dellaert, B.G.C. / Arentze, T.A. / Bierlaire, M. / Borgers, A.W.J. / Timmermans, H.J.P. (1998): "Investigating Consumers' Tendency to Combine Multiple Shopping Purposes and Destinations," Journal of Marketing Research 25, 177-178.

Dobson, P.W. (2002): "Retailer Buyer Power in European Markets: Lessons from Grocery Supply,” Working Paper, Loughborourgh University.

Dobson, P.W. / Clarke, R. / Davies, S. / Waterson, M. (2001): "Buyer Power and its Impact on Competition in the Food Retail Distribution Sector of the European Union," Journal of Industry, Competition and Trade 1, 247-281.

Dobson, P. W./ Inderst, R. (2007): “Differential Buyer Power and the Waterbed Effect,” European Competition Law Review 28, 393-400.

Dobson, P.W. / Waterson, M. (1997): “Countervailing Power and Consumer Prices,” Economic Journal 107, 418-430.

Dobson, P. W. / Waterson, M. / Davies, S.W. (2003): "The Patterns and Implications of Increasing Concentration in European Food Retailing,” Journal of Agricultural Economics 54, 111-126.

Dolan, C. / Humphrey, J. (2001): "Governance and Trade in Fresh Vegetables: The Impact of UK. Supermarkets on the African Horticultural Industry,” Journal of Development Studies 37(2), 147-176. 
European Commission (1999): "Buyer Power and its Impact on Competition in the Food Retail Distribution Sector of the European Union,” Report produced for the European Commission, D IV, Brussels.

Faini, R. / Haskel, J. / Navaretti, G.B. / Scarpa, C. / Wey, C. (2006): “Contrasting Europe’s Decline: Do Product Market Reforms Help?,” in Structural Reforms Without Prejudices, edited by T. Boeri, M. Castanheira, R. Faini, and V. Galasso, Oxford, Oxford University Press, 15-134.

Faulí-Oller, R. / Sandonís, J. / Santamaría, J. (2007): "Downstream mergers and upstream investments," mimeo.

Feenstra, R.C. / Hanson, G.H. (1996): “Globalization, Outsourcing, and Wage Inequality,” The American Economic Review 86(2), 240-245. Papers and Proceedings of the Hundredth and Eighth Annual Meeting of the American Economic Association San Francisco, CA, January 5-7, 1996.

FTC (2001): "Report on the Federal Trade Commission Workshop on Slotting Allowances and Other Marketing Practices in the Grocery Industry,” available at: http://www.ftc.gov/os/2001/02/slottingallowancesreportfinal.pdf

Fumagalli, C. / Motta, M. (2008): "Buyers' Miscoordination, Entry and Downstream Competition,” Economic Journal 118, $1196-1222$.

Galbraith, J.K. (1952): “American Capitalism: The Concept of Countervailing Power,” New York, Houghton Mifflin.

Gereffi, G. (2001): "Shifting Governance Structures in Global Commodity Chains, With Special Reference to the Internet,” American Behavioral Scientist 44(10), 1616-1637.

Gutman, G. E. (2002): "Impact of the Rapid Rise of Supermarkets on Dairy Products Systems in Argentina,” Development Policy Review, 20(4), 409-427.

Hart, O. / Tirole, J. (1990): “Vertical Integration and Market Foreclosure,” Brookings Papers on Economic Activity, Microeconomics, 205-276.

Inderst, R. / Irmen, A. (2005): "Shopping Hours and Price Competition,” European Economic Review 49, 1105-1124.

Inderst, R. / Shaffer, G. (2007): "Retail Mergers, Buyer Power and Product Variety,” Economic Journal 117, 45-67.

Inderst, R. / Valletti, T.M. (2008): "Buyer Power and the 'Waterbed Effect'," CEIS Working Paper No. 107.

Inderst, R. / Wey, C. (2003): "Bargaining, Mergers, and Technology Choice in Bilaterally Oligopolistic Industries,” RAND Journal of Economics 34, 1-19.

Inderst, R. / Wey, C. (2007a): "Buyer Power and Supplier Incentives,” European Economic Review 51, 641-667.

Inderst, R. / Wey, C. (2007b): “Countervailing Power and Dynamic Efficiency,” DIW Working Paper. 
Katz, M.L. (1987): "The Welfare Effects of Third-Degree Price Discrimination in Intermediate Good Markets,” American Economic Review 77, 154-167.

Kleinert, J. (2003): "Growing Trade in Intermediate Goods: Outsourcing, Global Sourcing, or Increasing Importance of MNE Networks?,” Review of International Economics 11, 464-482.

Lal, R. / Matutes, C. (1989): "Price Competition in Multi-Market Duopolies,” RAND Journal of Economics 20, 516-537.

Majumdar, A. (2006): “Waterbed effects, 'gatekeepers’ and buyer mergers,” mimeo.

McAfee, P. / Schwartz, M. (1994): "Opportunism in Multilateral Contracting: Nondiscrimination, Exclusivity and Uniformity,” American Economic Review 84, 210-230.

Morrison, S. / Newman, R. (1983): "Hours of operation restrictions and competition among retail firms,” Economic Inquiry 21, 107-114.

OECD (1998): "Buyer Power of Large Scale Multiproduct Retailers,” Background Paper by the Secretariat, Roundtable on Buying Power.

Potz, P. (2002): „Die Regulierung des Einzelhandels in Italien. Grundlagen und Einfluss auf die Handelsstruktur,”. Discussion paper FS I 02-104, WZB Berlin.

Raskovich, A. (2003): “Pivotal Buyers and Bargaining Position,” Journal of Industrial Economics 51, 405-426.

Reardon, T. / Gulati, A. (2003): "The Supermarket Revolution in Developing Countries. Policies for 'competitiveness with Inclusiveness',” IFPRI Policy Brief 2.

Reardon, T. / Timmer, P. / Berdegue, J. (2004): “The Rapid Rise of Supermarkets in Developing Countries: Induced Organizational, Institutional, and Technological Change in Agrifood Systems,” e Journal of Agricultural and Development Economics 1, 168-183.

Rey, P. / Tirole, J. (2007): “A Primer on Foreclosure,” In Handbook of Industrial Organization, edited by M. Armstrong and R.H. Porter, Volume 3, North-Holland, 2145-2220.

Rey, P. / Vergé, T. (2004): "Bilateral Control with Vertical Contracts,” RAND Journal of Economics 35, 728-746.

Sheffman, D.T. / Spiller, P.T. (1992): "Buyers' Strategies, Entry Barriers, and Competition,” Economic Inquiry 30, 418-436.

Smith, H. (2007): “Supermarket Choice with Multi-Shop Shopping,” mimeo.

Snyder, C.M. (1996): “A Dynamic Theory of Countervailing Power,” RAND Journal of Economics 27, 747-769.

Snyder, C.M. (1998): "Why Do Larger Buyers Pay Lower Prices? Intense Supplier Competition,” Economics Letters 58, 205-209.

Stahl, K. (1987): “Theories of Urban Business Location,” in Handbook of Urban Economics, edited by E.S. Mills, Volume 2, Amsterdam, Elsevier Science Publishers. 
Tanguay, G. / Vallge, L. / Lanoie, P. (1995): "Shopping hours and price levels in the retailing industry: A theoretical and empirical analysis,” Economic Inquiry 33(3), 516-524.

UK Competition Commission (2000): "Supermarkets: A Report on the Supply of Groceries from Multiple Stores in the United Kingdom,” Cm4842, TSO, London.

von Ungern-Sternberg, T. (1996): “Countervailing Power Revisited," International Journal of Industrial Organization 14, 507-520.

Williamson, O. (1975): "Markets and Hierarchies: Analysis and Antitrust Implications,” New York, Free Press.

Yoshida, Y. (2000): “Third-Degree Price Discrimination in Input Markets: Output and Welfare,” American Economic Review 90, 240-246. 